\title{
Introduction to the Handbook of Democratic Innovation and Governance: the field of democratic innovation Oliver Escobar and Stephen Elstub
}

\section{A TIME OF DEMOCRATIC CHALLENGES AND RENEWAL}

Welcome to this Handbook! You have in your hands the work of 60 authors brought together to offer a comprehensive overview of the field of democratic innovation across the globe. This introductory chapter places the Handbook in context, reflects on what the field has to offer, and outlines the key themes explored in six sections featuring 38 chapters.

We live in a time where the ideal of democracy is widely loved, but its practices are broadly criticised. Studies often highlight democratic deficits and the proliferation of a democratic malaise, while there is a growing debate about whether we are entering a period of global democratic recession (Diamond, 2015; Levitsky and Way, 2015). In the last decade there has been a reduction in the number of democratic systems, and established democracies are under increasing pressure due to social, political, environmental and economic factors (Wike and Fetterolf, 2018). Moreover, the gap between the 'politically rich' and the 'politically poor' is widening in societies across the world (Dalton, 2017).

A sobering overview was provided by the 2016 Democracy Index, where the global average score fell, with 72 countries dropping in the ranking from 2015, and just 38 moving up (The Economist Intelligence Unit, 2016: 3-6). The number of 'full democracies' dropped from 20 to 19 , with the US now classed as 'flawed'. Near half the world's population (49.3\%) live currently in a democracy of some kind, but only $4.5 \%$ of people live in a 'full democracy' half as many than in 2015 (ibid). The 2018 Democracy Index, in turn, indicates that growing disillusionment with democratic institutions is accompanied by growing political participation as people are 'turning anger into action' (The Economist Intelligence Unit, 2018: 4). Recent waves of the World Values Survey suggest increased frustration and authoritarian attitudes, with striking rises amongst the youngest populations of democratic systems around the world (Foa and Mounk, 2016).

Although democratic principles still enjoy support, current practices and institutions evoke cynicism: people love democracy, but often despair at how it is practiced. In this context, the field of democratic innovation is growing, in part, to counter the democratic recession. This has interesting parallels with debates that emerged a century ago during arguably the first contemporary wave of democratic innovation. Although debates about participatory democracy, more broadly, can be traced back to Athenian democracy, the narratives about innovation that occupy this Handbook were shaped in the past century ${ }^{1}$ (Escobar, 2017b). For example, John Dewey was a strong critic of the 'democratic elitism' that underpins mainstream narratives of representative democracy (Bernstein, 2010: 74). Dewey saw elitism as central to the demise of democracy and the advance of elite-driven populism and totalitarian regimes. This quote from 1937 remains topical today: 


\section{Handbook of democratic innovation and governance}

Everywhere there are waves of criticism and doubt as to whether democracy can meet pressing problems... Wherever it has fallen, [democracy] had not become part of the bone and blood of the people in daily conduct of its life. Democratic forms were limited to Parliament, elections and combats between parties. What is happening proves conclusively...that unless democratic habits of thought and action are part of the fiber of a people, political democracy is insecure. It cannot stand in isolation. It must be buttressed by the presence of democratic methods in all social relationships. (Dewey, 1937: 467)

Dewey understood democracy as more than a form of government. He saw it as a way of life and placed at its heart 'the necessity for the participation of every mature human being in formation of the values that regulate the living of [people] together', thus arguing that this is 'necessary from the standpoint of both the general social welfare and the full development of human beings as individuals' (Dewey, 1937: 457). The revival of these participatory imaginaries of democracy started in the 1960s (e.g. Pateman, 1970). They argued for developing a form of democracy that enables extensive participation of citizens in ongoing decision-making, whether it is at national or local level, or within communities or organisations (Saward, 2003: 149). Whereas representative democracy places the emphasis on the work of representatives, advocates and experts, participatory democracy compels all citizens to encounter other citizens without intermediaries, and therefore politics is seen as the art of participating in planning, coordinating and enacting collective action (Barber, 2003: 152-153).

Since the 1990s, deliberative theory and practice have built on, and rekindled, some of the ideals of participatory democracy (for an overview see Elstub, 2010, 2018). Indeed, deliberative democracy shares much with its participatory counterpart, but places a stronger emphasis on communication as a central dimension in citizen participation. This discursive focus is underpinned by the claim that 'political decision-making should be talk-centric rather than voter-centric' (Elstub and McLaverty, 2014b: 1). Deliberative democrats also highlight the inadequacy of 'aggregative conceptions', arguing that democracy is more than just counting heads: 'it must involve discussion on an equal and inclusive basis, which deepens participants' knowledge of issues, awareness of the interests of others, and the confidence to play an active part in public affairs' (Saward, 2000: 5). Democracy is thus seen not as 'a market for the exchange of private preferences' but as a discursive forum for the exchange of public reasons and the creation of public agreements (Parkinson, 2004: 379).

At the intersection of these models of democracy, the field of democratic innovation has proliferated since the turn of the century, bringing together diverse streams of democratic thought and action. This new field stems from the confluence of a range of practical and theoretical projects advancing the critique and development of democracy throughout the past century. However, the label 'democratic innovation' has only recently started to galvanise a burgeoning academic field built on notable publications (Smith, 2009; Hendriks, 2011; Geissel and Newton, 2012; Geissel and Joas, 2013; Grönlund et al., 2014; Lee, 2015; Font et al., 2014; Elstub and McLaverty, 2014a; Sintomer et al., 2016; Baiocchi and Ganuza, 2017). A critical component of this development has been the formation of new international research networks, for example, the Standing Group on Democratic Innovations at the European Consortium of Political Research ${ }^{2}$ or the databases developed by Participedia ${ }^{3}$ and the LATINNO project $^{4}$ (see Chapters 26 and 38).

Our scoping review of the literature (see Chapter 1) shows that the concept of democratic innovation had limited usage prior to the early 2000 s and $75 \%$ of the relevant publications are from the year 2010 onwards. At that point, the concept was gaining scholarly currency with 
milestone publications shaping the field (i.e. Smith, 2005, 2009). The term has been also increasingly used in initiatives by governments and NGOs, such as the Open Government Partnership, which declared at its 2016 Paris summit: 'The Partnership gathers today 70 member countries and hundreds of civil society organizations that promote transparency, citizen participation and democratic innovation.' 5 The initiative connects key actors currently confronting the challenges of democracy across the globe, and illustrates how democratic innovations have concurrently become matters of governmental concern, as well as new sites for civil society mobilisation.

As this Handbook shows, democratic innovations are proliferating in all areas of governance, from politics to policy and public administration. These new processes and institutions seek to reimagine and deepen the role of citizens in public governance and collective decisionmaking (see our full definition and typology in Chapter 1). Can these democratic innovations offer an antidote to the democratic recession? Can they help to develop ways of governing that can meet the challenges of the century ahead? These and other fundamental questions are the focus of this emerging field of inquiry.

\section{THE FIELD OF DEMOCRATIC INNOVATION AS POINT OF ENCOUNTER}

We acknowledge that any endeavour to systematise an emerging field carries risks, not least that of reification as we are not just reflecting but also reproducing and shaping the field. There are reasonable questions about whether the terminology of 'democratic innovation' is adequate (see Chapter 38) and whether its areas of inquiry are skewed towards particular types of processes to the exclusion of others (Hendriks and Dzur, 2015, 2018; Hendriks, 2019).

We argue, however, that the added value of the term resides in the liminality it provides to bring together, expand and deepen our understanding of the field. In this sense, it functions as a meeting point for a range of ideas, disciplines, traditions, and methodologies. Part of the concept's appeal is that it carves up space to overcome a series of dualisms inherited from various fields of inquiry and practice:

- Between participatory and deliberative democracy. The field of democratic innovation accommodates both participatory and deliberative traditions, thus bridging key groundwork carried out over the last 60 years.

- Between representation and other democratic practices. The field seeks to explore and demonstrate the compatibility of representative, participatory, and deliberative logics in configuring new practices of democratic governance.

- Between politics and policy. The field seeks to transcend artificial separations of the worlds of policy and politics by reintroducing normative judgement (by citizens) to disrupt the technocratic impulses of the New Public Management era (Baiocchi and Ganuza, 2017; Fischer, 2009). Democratic innovations are political sites for collective action bounded by the realpolitik of policy crucibles in the new public governance.

- Between state and civil society. The field opens space to rethink the oppositional framing of the relationship between state and civil society, by building new processes and 
arenas for citizen participation that try to constitute an interface, or liminal space, between both that is distinct from each (Escobar, 2014).

- Between normative and empirical concerns. The field has developed as a meeting point for those wrestling with the perennial issue of the practice of the normative. As such, it has contributed to cut across silos to accommodate scholars and practitioners from a range of disciplines and fields - from politics to urban studies, public administration, environment, education, health and constitutional reform, to name but a few.

A significant achievement is that the term 'democratic innovation' has provided a shared language for researchers and practitioners. The importance of this should not be underestimated. Knowledge exchange and co-production requires a shared vocabulary that helps to generate dialogue between inquiry and practice. The label 'democratic innovation' has proven an effective bridge. One may not get an enthusiastic response when inviting someone to discuss 'new democratic intersections of participatory, deliberative and representative practices', but talking about 'democratic innovations' tends, in our experience, to resonate or at least inspire curiosity. In doing so, it provides a starting point for public understanding and shared inquiry and this can only help to advance a field that benefits from a sustained and creative relationship between research and practice. There is, nonetheless, much work to be done in growing, troubling and developing this field, and we think this Handbook makes a substantial contribution to those endeavours.

\section{WHAT IS INCLUDED IN THIS HANDBOOK?}

In Chapter 1, we differentiate between democratic innovation - the practice - and democratic innovations - the processes that embody the practice. The sections of this Handbook cover both dimensions. People may engage in the practice of democratic innovation through a variety of roles, as activists, designers, sponsors, evaluators, entrepreneurs, supporters, researchers, gate-keepers or facilitators. To understand democratic innovation as a field of practice, this Handbook dedicates Sections 3, 4 and 6, to understanding the myriad actors and contexts that shape the field. In turn, Sections 1, 2 and 5, focus on the study of key types and cases of democratic innovations, as well as critical issues about citizenship and political culture.

Section 1 provides theoretical and empirical foundations to understand this field. Despite the rapid increase of democratic innovations employed in governance, policy, and public administration processes around the world, and sustained academic interest and debates about their use, there is little agreement about which governance processes should be classified as democratic innovations. This section offers a critical review of the different and dominant definitions currently in use, in order to provide an analytical typology that can provide greater clarity and coherence to the use of the term (Chapter 1). This is then developed through a discussion of how democratic innovations relate to alternative democratic theories (Chapter 2). Some of the most prominent cases in democratic innovation, including mini-publics (Chapter 3 ), collaborative governance (Chapter 4), participatory budgeting (Chapter 5), referendums and citizens' initiatives (Chapter 6) and digital participation (Chapter 7) are then explored at length. 
Section 2 places democratic innovations in the context of current challenges. It is now widely considered that a democratic malaise is sweeping through established democracies. This malaise is characterised by declining levels of participation in traditional avenues such as, elections and political parties; declining levels of trust in politicians and democratic institutions (Chapter 8); and growing concerns about forms and levels of accountability in representative systems (Chapter 9), which are, in camera, seen as drivers for an emergence of anti-politics (Chapter 10) and affect developments related to social capital and political efficacy (Chapter 11). This is the context in which the increased use of, and attention to, democratic innovation is taking place, and this section analyses the extent to which democratic innovations are helping to cure the various, and related, aspects of the democratic malaise.

Section 3 is dedicated to exploring key actors in the field. The world of democratic innovation is populated by a range of actors engaged in the puzzling process of redefining and reinventing ways of doing politics and policymaking. Accordingly, the study of democratic innovation must pay attention to the actions, interactions, motivations, challenges and dilemmas of the agents involved in new democratic practices. The focus on citizens is an overarching theme of the Handbook, therefore in this section other key actors are examined, including the emerging industry of participation (Chapter 13); the role of process designers and facilitators (Chapter 12); the work of institutional entrepreneurs opening official spaces for democratic innovation (Chapter 14); the role of experts and expertise (Chapter 15); and the repositioning of traditional political players such as politicians, advocates and journalists (Chapters 16, 17 and 18).

Section 4 offers a guided analytical tour of democratic innovations in a variety of policy and governance contexts. The proliferation of democratic innovations across policy processes and levels of governance can be understood as part of the trend of governance-driven democratisation (Warren, 2009). That is, much democratic innovation has emerged in the context of the alleged transition from hierarchical government to networked governance across liberal democracies and beyond. Therefore, perhaps surprisingly, many spaces for democratic innovation are rooted in policymaking processes rather than in the more traditional arenas of political decision-making. This section examines the role of democratic innovations in the policymaking process (Chapter 19); the range of policy areas where democratic innovations have been prominent, including science and technology, social policy, environmental governance and constitutional reform (Chapters 20, 21, 22 and 23); and their development across multiple levels, including transnational and global governance (Chapter 24).

Section 5 zooms out in order to provide insights into democratic innovations around the globe. The deployment of democratic innovations is increasingly becoming a global phenomenon as they are utilised in established democracies, countries undergoing democratic consolidation and transition, authoritarian states and in transnational governance. However, the types of democratic innovations used, the manner in which they have been developed, and the effects they have produced, vary considerably around the world. This section therefore provides a global perspective on the use of democratic innovations in each continent, from North and Latin America (Chapters 25 and 26), to Africa (Chapter 30), Europe (Chapter 27), Asia (Chapter 28) and Australasia (Chapter 29). The work undertaken by these authors represents the first attempt to carry out state-of-the-art continental surveys.

Section 6 introduces a wide range of strategies and methods for the study of democratic innovations. New fields of research tend to accommodate a variety of approaches to scholarly 
inquiry. The field of democratic innovation is no exception and is thus characterised by multiple paradigms and methodologies. This pluralism is to be welcomed as theories of democratic innovation try to develop empirical grounding. However, it can result in piecemeal approaches that prevent systematic comparison and methodological rigour. This section takes on the challenge of providing an overview of key approaches to research on democratic innovations, as well as exploring current and future options for methodological development. It includes chapters on quantitative (Chapter 31), qualitative (Chapter 32) and mixed methods (Chapter 33), as well as the use of experiments (Chapter 34), new developments in the Discourse Quality Index (Chapter 35), multi-level approaches using Q methodology (Chapter 36) and comparative work (Chapter 37).

Finally, the concluding chapter is penned by a key steward of the field, whose work has provided strong foundations for a new generation of scholarship. We are thankful to Graham Smith for his support of this Handbook as well as for the thought-provoking chapter (Chapter 38 ) that closes this volume by taking the pulse of the field, looking back to draw critical learning, and looking forward to advance research.

\section{THE END OF THE BEGINNING?}

Prominent post-war theorists constructed a narrative of democracy that emphasised leadership, competition, aggregation and minimalist citizenship (Böker and Elstub, 2015; Escobar, 2017b). This understanding of representative democracy became so influential that many subsequent scholars felt no need to justify it. Indeed, it became the mainstream narrative, and the benchmark by which democracy was to be understood, measured and analysed. Accordingly, as Saward (2003: 42-47) explains, important ideological assumptions were built into that narrative and presented as mere descriptions of the 'reality' of democratic politics. Amongst the critics of this narrative, however, were participatory democrats who since the 1960s rekindled the pre-war ashes of Dewey's vision for democracy and participation. Participatory democracy grew, in theory and practice, thus permeating mainstream narratives with strong arguments about pluralism, inclusion, and citizen empowerment. Since the 1990s, deliberative democrats built on participatory ideals, but also developed distinct normative and practical dimensions around the communicative fabric of democracy (Elstub, 2018).

In the last two decades, there have been robust theoretical and empirical critiques of participatory and deliberative democracy, and the challenges of turning ideals into practices have become apparent. This has rekindled debates over whether citizens are willing and capable of participating and deliberating (e.g. Hibbing and Theiss-Morse, 2002; Neblo et al., 2010); how to ensure inclusion and diversity, and their effects on group dynamics (e.g. Young, 2000; Mutz, 2006; Sunstein, 2009); whether participation and deliberation are feasible in the face of interest-based politics (e.g. Forester, 1988, 2009; Shapiro, 1999; Hendriks, 2011); whether participatory processes seek enrolment and co-option rather than empowerment (e.g. Cooke and Kothari, 2001; Cornwall and Coelho, 2007); whether emancipatory practices are giving way to technocratic or depoliticised participatory processes (Lee, 2015; Baiocchi and Ganuza, 2017); and the challenge of scaling up deliberation to develop large deliberative systems (Parkinson and Mansbridge, 2012; Owen and Smith, 2015).

These areas of research are work in progress, but the chapters in this Handbook demonstrate how scholars are taking these challenges seriously by developing an ambitious agenda of 
theoretical and empirical work. Democratic innovation, as a field, is still in its developmental stages and it is important to chart a course that is critical without being cynical. This Handbook seeks to go beyond the uncritical optimism of some advocates of democratic innovation, while avoiding the complacency of those who think that the status quo is acceptable.

The Handbook highlights two significant trends that are expanding and deepening the field in both theory and practice. On the one hand, there is a clear move towards hybridisation, with processes and institutions that combine the principles and practices of various democratic innovations (see Chapter 1; also Sintomer, 2018; Hendriks, 2019). On the other hand, there is also a move towards institutionalisation, seeking to append or embed democratic innovations as part of the formal institutional landscape in various polities (e.g. Bua and Escobar, 2018; Weakley and Escobar, 2018; Escobar et al., 2018; Escobar, 2017a; Ravazzi, 2016; Font et al., 2014; Nabatchi et al., 2012; Wampler, 2012; Lewanski, 2013). These are fruitful areas for research in this Handbook and in years to come, with new opportunities offered by underexplored connections to fields such as social innovation and the commons (Coote, 2017; Brandsen et al., 2016; Henderson et al., 2018).

Following the continuing dispersion, in breadth and depth, of a democratic malaise, accompanied by the move from government to governance and the increasing intensity of globalisation, democracy in the 21 st century is widely considered to be suffering a legitimation crisis, along with problems of efficiency and efficacy. Despite this, citizens' faith in the ideal of democracy as the best form of governance seems undiminished and indeed it is suggested that a post-material ethos is flourishing, leading citizens around the world to demand more opportunities for meaningful participation in public affairs. This situation presents a challenge for democracies, but also the opportunity for change. The development of democratic innovations is increasingly taking hold around the world in governance, policy, and public administration processes in order to address this crisis.

Despite increased academic attention to this burgeoning field, no Handbook has yet been published to provide a global analysis of democratic innovations in theory and practice. Consequently, this volume seeks to advance understanding of democratic innovations by bringing together international experts in the field to critically review and assess the importance of different types of democratic innovations conceptually and contextually, through empirical and normative analysis. The Handbook therefore offers a definitive overview of existing research on democratic innovations, while it also sets the agenda for future inquiry by providing cutting-edge insight into critical issues, illustrative cases, alternative methods and diverse impacts. We share with our co-authors the hope that this volume will satisfy curiosity and inspire action.

\section{NOTES}

1. Parts of this chapter draw on Escobar (2017b), with thanks to the journal Contemporary Pragmatism.

2. See http://standinggroups.ecpr.eu/democraticinnovations/.

3. See https://participedia.net.

4. See www.latinno.net/en/.

5. The Open Government Partnership summit involved: ' 3000 representatives from 70 countries: Heads of State and governments, ministers, public servants, members of parliament, local authorities, civil society representatives, start-ups and digital innovators, civic techs, developers, researchers, journalists will gather in Paris to share their experiences and push forward the open government agenda in light of the global challenges.' See https:// en.ogpsummit.org/osem/conference/ogp-summit. 


\section{REFERENCES}

Baiocchi, G. and E. Ganuza (2017), Popular Democracy: The Paradox of Participation, Stanford, CA: Stanford University Press.

Barber, B.R. (2003), Strong Democracy. Participatory Politics for a New Age (20th Anniversary Edition ed.), London: University of California Press.

Bernstein, R.J. (2010), The Pragmatic Turn, Cambridge: John Wiley \& Sons.

Böker, M. and S. Elstub (2015), 'The possibility of critical mini-publics: Realpolitik and normative cycles in democratic theory', Representation, 51 (1), 125-144.

Brandsen, T., S. Cattacin, A. Evers and A. Zimmer (2016), Social Innovations in the Urban Context, Cham: Springer International Publishing.

Bua, A. and O. Escobar (2018), 'Participatory-deliberative processes and public policy agendas: Lessons for policy and practice', Policy Design and Practice, 1 (2), 126-140.

Cooke, B. and U. Kothari (eds) (2001), Participation. The New Tyranny?, London: Zed Books.

Coote, A. (2017), Building a New Social Commons: The People, the Commons and the Public Realm, London: New Economics Foundation.

Cornwall, A. and V. Schattan P. Coelho (2007), Spaces for Change? The Politics of Citizen Participation in New Democratic Arenas, London: Zed.

Dalton, R.J. (2017), The Participation Gap: Social Status and Political Inequality, Oxford: Oxford University Press.

Dewey, J. (1937), 'Democracy and educational administration', School and Society, 45, 457-467.

Dewey, J. (1984), The Later Works, 1925-1927, Carbondale, IL: Southern Illinois University Press.

Diamond, L. (2015), 'Facing up to the democratic recession', Journal of Democracy, 26 (1), 141-155.

Elstub, S. (2010), 'The third generation of deliberative democracy', Political Studies Review, 8 (3), 291-307.

Elstub, S. and P. McLaverty (2014a), Deliberative Democracy: Issues and Cases, Edinburgh: Edinburgh University Press.

Elstub, S. and P. McLaverty (2014b), 'Introduction: Issues and cases in deliberative democracy', in S. Elstub and P. McLaverty (eds), Deliberative Democracy: Issues and Cases, Edinburgh: Edinburgh University Press, pp. 1-16.

Elstub, S. (2018), 'Deliberation and participatory democracy', in A. Bächtiger, J.S. Dryzek, J. Mansbridge and M.E. Warren (eds), The Oxford Handbook of Deliberative Democracy, Oxford: Oxford University Press.

Escobar, O. (2014), Transformative Practices: The Political Work of Public Engagement Practitioners, PhD Thesis, University of Edinburgh, accessed 10 August 2019 at www.era.lib.ed.ac.uk/handle/1842/9915, Edinburgh.

Escobar, O. (2017a), 'Making it official: Participation professionals and the challenge of institutionalizing deliberative democracy', in L. Bherer, M. Gauthier and L. Simard (eds), The Professionalization of Public Participation, New York and London: Routledge, pp. 141-164.

Escobar, O. (2017b), 'Pluralism and democratic participation: What kind of citizen are citizens invited to be?', Contemporary Pragmatism, 14, 416-438.

Escobar, O., F. Garven, C. Harkins, K. Glazik, S. Cameron and A. Stoddart (2018), 'Participatory budgeting in Scotland: The interplay of public service reform, community empowerment and social justice', in N. Dias (ed.), Hope for Democracy: 30 Years of Participatory Budgeting Worldwide, Vila Ruiva, Cuba; Faro, Portugal: Epopeia Records \& Oficina, pp. 311-336.

Fischer, F. (2009), Democracy and Expertise: Reorienting Policy Inquiry, Oxford: Oxford University Press.

Foa, R.S. and Y. Mounk (2016), 'The danger of deconsolidation', Journal of Democracy, 27 (3), 5-17.

Font, J., D. della Porta and Y. Sintomer (2014), Participatory Democracy in Southern Europe: Causes, Characteristics and Consequences, London and New York: Rowman \& Littlefield International.

Forester, J. (1988), Planning in the Face of Power, Berkeley, CA: University of California Press.

Forester, J. (2009), Dealing with Differences: Dramas of Mediating Public Disputes, Oxford: Oxford University Press.

Geissel, B. and M. Joas (2013), Participatory Democratic Innovations in Europe: Improving the Quality of Democracy?, Berlin and Toronto: Barbara Budrich Publishers.

Geissel, B. and K. Newton (2012), Evaluating Democratic Innovations. Curing the Democratic Malaise?, London: Routledge.

Grönlund, K., A. Bächtiger and M. Setälä (eds) (2014), Deliberative Mini-Publics: Involving Citizens in the Democratic Process, Colchester, UK: ECPR Press.

Henderson, J., P. Revell and O. Escobar (2018), Transforming Communities? Exploring the Roles of Community Anchor Organisations in Engaging with, Leading and Challenging Public Service Reform, Edinburgh: What Works Scotland.

Hendriks, C. (2011), The Politics of Public Deliberation: Citizen Engagement and Interest Advocacy, Basingstoke: Palgrave Macmillan.

Hendriks, C. and A.W. Dzur (2015), Innovating in the Mainstream? Enhancing Public Deliberation in Conventional Politics, paper presented at the European Consortium of Political Research Annual Conference, Montreal. 
Hendriks, C. and A.W. Dzur (2018), Citizen Agency in Democratic Reform: Towards Substantive and Sustainable Democratic Innovation, paper presented at the European Consortium of Political Research Joint Sessions, Nicosia.

Hendriks, F. (2019), 'Democratic innovation beyond deliberative reflection: The plebiscitary rebound and the advent of action-oriented democracy', Democratization, 26 (3), 444- 464.

Hibbing, J.R. and E. Theiss-Morse (2002), Stealth Democracy: Americans'Beliefs About How Government Should Work, Cambridge: Cambridge University Press.

Lee, C.W. (2015), Do-it-yourself Democracy: The Rise of the Public Engagement Industry, New York: Oxford University Press.

Levitsky, S. and L. Way (2015), 'The myth of democratic recession', Journal of Democracy, 26 (1), 45-58.

Lewanski, R. (2013), 'Institutionalizing deliberative democracy: The "Tuscany laboratory"', Journal of Public Deliberation, 9 (1), Article 10.

Mutz, D.C. (2006), Hearing the Other Side: Deliberative Versus Participatory Democracy, Cambridge: Cambridge University Press.

Nabatchi, T., J. Gastil, G. Michael Weiksner and M. Leighninger (2012), Democracy in Motion: Evaluating the Practice and Impact of Deliberative Civic Engagement, New York: Oxford University Press.

Neblo, M.A., K.M. Esterling, R.P. Kennedy, D.M.J. Lazer and A.E. Sokhey (2010), 'Who wants to deliberate - and why?', American Political Science Review, 104 (3), 1-18.

Owen, D. and G. Smith (2015), 'Survey article: Deliberation, democracy, and the systemic turn', Journal of Political Philosophy, 23 (2), 213-234.

Parkinson, J. (2004), 'Why deliberate? The encounter between deliberation and new public managers', Public Administration, 82 (2), 377-395.

Parkinson, J. and J. Mansbridge (eds) (2012), Deliberative Systems: Deliberative Democracy at the Large Scale, Cambridge: Cambridge University Press.

Pateman, C. (1970), Participation and Democratic Theory, Cambridge: Cambridge University Press.

Ravazzi, S. (2016), 'When a government attempts to institutionalize and regulate deliberative democracy: The how and why from a process-tracing perspective', Critical Policy Studies, 11 (1), 79-100.

Saward, M. (ed.) (2000), Democratic Innovation: Deliberation, Representation, and Association, London: Routledge.

Saward, M. (2003), Democracy, Cambridge: Polity in association with Blackwell.

Shapiro, I. (1999), 'Enough of deliberation: Politics is about interests and power', in S. Macedo (ed.), Deliberative Politics: Essays on Democracy and Disagreement, New York: Oxford University Press, pp. 28-38.

Sintomer, Y. (2018), 'From deliberative to radical democracy: sortition and politics in the 1st century', Politics and Society, 46 (3), 337-357.

Sintomer, Y., A. Röcke and C. Herzberg (2016), Participatory Budgeting in Europe: Democracy and Public Governance, Abingdon: Routledge.

Smith, G. (2005), Beyond the Ballot. 57 Democratic Innovations from Around the World - A report for the POWER Inquiry, accessed 25 August 2011 at www.powerinquiry.org/.

Smith, G. (2009), Democratic Innovations: Designing Institutions for Citizen Participation, Cambridge: Cambridge University Press.

Sunstein, C.R. (2009), Going to Extremes: How Like Minds Unite and Divide, Oxford: Oxford University Press.

The Economist Intelligence Unit (2016), Democracy Index 2016. Revenge of the 'Deplorables', London: The Economist.

The Economist Intelligence Unit (2018), Democracy Index 2018: Me Too? Political Participation, Protest and Democracy, London: The Economist.

Wampler, B. (2012), 'Entering the state: Civil society activism and participatory governance in Brazil', Political Studies, 60 (2), 341-362.

Warren, M. (2009), 'Governance-driven democratization', Critical Policy Studies, 3 (1), 3-13.

Weakley, S. and O. Escobar (2018), Community Planning after the Community Empowerment Act. Edinburgh: What Works Scotland.

Wike, R. and J. Fetterolf (2018), 'Liberal democracy's crisis of confidence', Journal of Democracy, 29 (4), 136 -150.

Young, I.M. (2000), Inclusion and Democracy, Oxford: Oxford University Press. 